\title{
Determinants of Corporate Dividends Policy: Evidence from an Emerging Economy
}

\author{
Marwan Abu Manneh ${ }^{1} \&$ Kamal Naser ${ }^{2}$ \\ ${ }^{1}$ Univest Group, UAE \\ ${ }^{2}$ Financial Advisor: Kuwait Fund, UK \\ Correspondence: Kamal Naser, Financial Advisor: Kuwait Fund, 36 Amesbury Road, Penylan, Cardiff CF23 \\ 5DX, KU. E-mail: profnaser@yahoo.co.uk
}

Received: March 20, 2015

Accepted: April 27, 2015

Online Published: June 25, 2015

doi:10.5539/ijef.v7n7p229

URL: http://dx.doi.org/10.5539/ijef.v7n7p229

\begin{abstract}
The objective of this study is to establish the relationship between dividend policy and the attributes of non-financial companies listed on Abu Dhabi Securities Exchange (ADX). The companies comprise manufacturing, services, food staples, energy, telecommunications and property and real estate. To achieve this objective, panel data for the period between 2010 and 2012 were collected from the listed companies' annual reports published on ADX website. The result of the analysis revealed that dividend policy is positively and significantly associated with corporate profitability, risk, free cash flows, size, majority shareholders and industry. Dividend policy, however, appeared to be negatively and significantly associated with corporate level of leverage. The result supports agency theory.
\end{abstract}

Keywords: dividend policy, non-financial companies, Abu Dhabi Securities Exchange (ADX)

\section{Introduction}

Numerous studies have been undertaken to explain dividend policy. Despite these studies, the issue of what determines corporate dividend policy is still unresolved. Dividend policy is important for any company since it is used as a mechanism to signal to the outside world information about a company's prospect of stability and growth (Naser et al, 2013). Shareholders and potential investors formulate investment impressions about companies by looking into management's ability to initiate dividends. In addition, dividend policy affects the capital structure and investment decision of the company. Hence, dividend policy can be used by management as well as shareholders to minimize agency costs ${ }^{(2)}$. Managers' success is measured by their ability to maximize shareholders wealth. To ensure success, managers need to fully understand dividend policy mechanism.

Although dividend policy is important to all companies, no research has been undertaken, so far, to examine determinants of dividend policy of companies operating in the UAE. In this study, an attempt is made to investigate dividend policies of non-financial companies listed on Abu Dhabi Securities Exchange (ADX). The importance of this study stems from the fact that few studies were undertaken to explore determinants of dividend policy in emerging economies. Dividend policy in emerging economies is not similar to that experienced by companies operating in developed economies. Emerging economies like the Gulf Cooperation Council (GCC) countries, including the UAE, have distinctive characteristics. GCC countries have surplus in their budgets from oil revenues. In addition, governments in these countries play an active role in their economies. Consequently, these countries do not face liquidity problems faced by many other developed countries. At the same time, these countries run thin stock markets with small number of listed companies and corporate ownership is concentrated in the hands few investors and government. This makes these markets instable, results in information asymmetry and increases agency cost. More importantly, tax on dividends and on capital gains was used to explain corporate dividend policy. In GCC countries tax is not paid on dividends or on capital gains. Hence, it is of paramount important to explore dividend policy of non-financial companies listed on ADX.

The remainder of the study is organized as follows. Previous related studies and hypotheses development are presented in the following section. Data collection and study methodology are summarized in section three. While the empirical findings are explained in section four, the conclusion is offered in the last section. 


\section{Previous Related Studies and Hypotheses Development}

Several studies were undertaken to identify factors affecting corporate dividend policy. Among these factors were corporate size, industry type, majority shareholders, level of corporate leverage, free cash flows and risk. Literature related to each of these factors will be reviewed.

\subsection{Corporate Size}

One of the main factors advanced in the literature to explain corporate dividend policy is corporate size (see for example: Lloyd et al., 1985; Eddy \& Seifert, 1988; Holder et al., 1998; Jensen et al., 1992; Redding, 1997; Fama \& French, 2000, 2001; Manos, 2002; Mollah, 2002; Al-Kuwari, 2009; Kouki \& Guizani, 2009; Al-Shubiri, 2011; Subramaniam et al., 2011; Kim et al., 2013; Baah et al., 2014; Movalia \& Vekariya, 2014; Saeed et al., 2014; Kumar \& Whaheed, 2015). Large companies tend to pay more dividends than small companies since the prospect of growth and expansion in their activities are less than small companies. Hence, they do not need to retain a significant part of their profit for future expansion and growth. Large companies are always noticeable and subject to the scrutiny of the outside market. They might use dividend payout to signal information about themselves.

An additional reason that explains possible association between dividend policy and corporate size is transaction costs. Large companies may have access to different sources of funds than small companies. The cost of funding for large companies is usually less than that paid by small companies. Easy access to the capital market together with low funding cost allow large companies management to pay more dividend than small companies. Large companies may further use dividend to reduce agency costs. In this respect, Jensen and Meckling (1976) pointed to a possible relationship between corporate size and agency costs. They believe that large firms usually have a widely spread ownership. This would result in greater bargaining control that might increase agency costs. In the same fashion, Sawicki (2009) indicated that dividend payouts could be used to scrutinize large firms' management. In other words, ownership is widely spread in large firms and this would result in an increase in information that restricts shareholders' ability to monitor the activities of these firms. In an attempt to reassure shareholders, management may choose to pay more dividends and this will increase its need to look for external funding. This move will subject management to the scrutiny of a third party (external financier). It is, therefore, hypothesized that:

Hypothesis 1: Dividend payout is positively associated with corporate size.

\subsection{Corporate Profitability}

Dividends paid to shareholders out of corporate profits. Changes in dividend payout are likely to be influenced by fluctuations in the levels of the achieved annual profit. A corporation is therefore likely to increase its dividend payout alongside with rising profits. Profit is, therefore, viewed as a major factor in formulating corporate dividend policy.

Several previous studies used profit to explain corporate dividend policy (see for example: Jensen et al., 1992; Han et al., 1999; Adaoğlu, 2000; Fama \& French, 2000; Wang et al., 2002; Nnadi \& Akpomi, 2008; Al-Kawari, 2009; Kouki \& Guizani, 2009; Franklin \& Muthusamy, 2010; Gill et al., 2010; Al-Shubiri, 2011; Subramaniam et al., 2011, Kim et al., 2013; Salehnezhad, 2013; Movalia \& Vekariya, 2014). It is not necessary, however, for the company to pay dividends only when they achieve high levels of profit. Fudenberg and Tirole (1995) revealed that while corporate management may choose to pay dividends even when their corporations' performance is below expectations, they might be reluctant to pay dividends or to increase the percentage of dividend payout when they report good levels of profit. By doing so, they calm down shareholders and contain their anger. In all cases, different measures are used in the literature to proxy profitability such as net profit, return on equity, return on assets, earnings per share and others. Empirical evidence on the relationship between dividend payout and profitability pointed to a certain association between the two variables. It is, therefore, hypothesized that:

Hypothesis 2: Dividend payout is positively associated with corporate profitability.

\subsection{Growth Opportunities}

Dividend policy is also affected by corporate growth opportunities. Companies with the prospect of future growth opportunities tend to retain significant part of their profit to use it as an internal source of financing these opportunities. Companies choose to use retained profit rather than external sources of funding since it is easier to obtain, incur less cost and less risky. Relying on internal sources of funding will leave less profit to be distributed as dividends hence, reducing dividend payout. In return, companies experiencing slow growth and have few investment opportunities may distribute a big proportion of their reported profit as dividends. On the other hand, companies with investment opportunities and operating in countries with low legal protection to shareholders 
may have high dividend payout. They tend to increase their dividend payout in order to develop or maintain their reputation and assure shareholders. The relationship between dividend payout and corporate growth has been examined by several researchers (see for example: Rozeff, 1982; Myers \& Majluf, 1984; Lloyd et al., 1985; Titman \& Wessels, 1988; Lang \& Litzinberger, 1989; Murrali \& Welch, 1989; Jensen et al., 1992 ; Alli et al., 1993; Holder et al., 1998; D’Souza, 1999; Manos, 2002; Gadhoum, 2000; La Porta et al., 2000; Al-Kawari, 2009; Kouki \& Guizani, 2009; Franklin \& Muthusamy, 2010; Gill et al., 2010; Al-Shubiri, 2011; Kim et al., 2013; Movalia \& Vekariya, 2014; Baah et al., 2014). However, the strength and the direction of the relationship between corporate growth and its dividend policy is not clear. It is, therefore, hypothesized that:

Hypothesis 3: Dividend payout is associated with corporate investment opportunities (growth).

\subsection{Ownership Structure}

As a result of the divorce between management and ownership an agency relation emerged between management and shareholders where management becomes an agent to the shareholders in running their money. Conflict of interest is likely to occur between management and shareholders. While shareholders expect management to make decisions that maximize their wealth, management might take decision to maximize its compensation. Hence, a conflict of interest emerges and results in an increase in agency cost. Agency cost results from shareholders monitoring management behavior. One of the mechanisms used to monitor management behavior is to reduce funds available to management. Hence, the structure of the ownership is very likely to influence corporate dividend policy. Management may go for high dividend payout to be forced to use external funding. By doing so, management invites a third part to monitor its behavior and therefore assure shareholders about its intention. Thus corporate ownership structure will dictate the monitoring policy and in turn would influence dividend policy. Large shareholders in a company have an incentive to monitor management due to the substantial amount that they invested in the company. In an attempt to assure them, management may have high dividend payout.

The relationship between corporate ownership structure and dividend policy is documented in several studies (see for example: Shleifer \& Vishny, 1986; Morck et al., 1988; Schooley \& Barney, 1994; Bebchuk, 1999; Han et al., 1999; La Porta et al., 1999; La Porta et al., 2000; Short et al., 2002; Gugler \& Yurtoglu, 2003; Chen et al., 2005; Jain, 2007; Renneboog \& Trojanowski, 2007; Truong \& Heaney, 2007; Abdelsalam et al., 2008; Al-Kawari, 2009; Kouki \& Guizani, 2009; Mehrani et al., 2011; McKnight \& Weir, 2009; Subramaniam et al., 2011; Thanatawee, 2013; Sáez \& María Gutiérrez, 2014). Empirical evidence on the relationship between corporate ownership structure and corporate policy is not consistent. It, therefore, hypothesized that:

Hypothesis 4: Dividend payout is associated with corporate structure of ownership.

\subsection{Leverage}

Another variable used in the literature to explain corporate dividend policy is leverage (see for example: Rozeff, 1982; Crutchley \& Hansen, 1989; Jensen et al., 1992; Fan \& Sundaresan, 2000; Eriotis \& Vasiliou, 2006; Franklin \& Muthusamy, 2010; Asif et al., 2011; Al-Shubiri, 2011; Subramaniam et al., 2011; Utami \& Inanga, 2011; Kim et al., 2013; Cheng et al., 2014; Movalia \& Vekariya, 2014). Corporations can either finance their growth through internal sources (retained earnings) or through external sources (equity or debt). dividend payout is influenced by retained earnings. Corporations with high dividend payout will be left with less retained earnings to be used for future expansion. This might force these companies to look for external sources of financing. High dividend payout may result in borrowings. Hence, a relationship exists between dividend policy and corporate leverage. When a company is in shortage of cash due to high dividend payout, management will consider either issuing additional shares or look for lenders. In this case, the company needs to strike a balance between dividend payout, leverage and shares issue. However, empirical evidence on the strength and direction of the relationship between dividend payout and leverage is inconsistent. It is, therefore, hypothesized that:

Hypothesis 5: Dividend payout is associated with the level of corporate leverage.

\subsection{Free Cash Flows}

It is argued that corporate cash position can be an important determinant of dividend payout. While a strong liquidity position enables the firm to set high dividend payout, a weak liquidity position may result in low dividend payout. The level of dividend payout is determined by availability of free cash flows. Hence, availability of cash flows is considered more important that availability of earnings since earnings do not really reflect the firm's ability to pay cash dividends. The relationship between dividend payout and free cash flows is documented by many researchers (see for example: Lang \& Litzenberger, 1989; Agrawal \& Jayaraman, 1994; Denis, 1994; Bradley et al., 1998; La Porta et al., 2000; Al-Kawari, 2009; Fairchild, 2010; Al-Shubiri, 2011; Subramaniam et al., 2011; Thanatawee, 2011; Utami \& Inanga, 2011; Kim et al., 2013; Chen et al, 2014). Although these researchers 
believe that a positive relationship is likely to exist between availability of positive cash flows and dividend payout, other researchers believe that availability of free cash flows may encourage management to engage in wasteful practices and may escalate agency conflict. Yet, it can be argued that availability of free cash flows may motivate management to increase dividend payout in order to minimize agency costs. It is, therefore, hypothesized that:

Hypothesis 6: Dividend payout is associated with availability of free cash flows.

\subsection{Corporate Risk}

An additional variable used in the literature to explain corporate dividend payout is corporate risk (see for example: Rozeff, 1982; Alli et al., 1993; Moh'd et al., 1995; Casey \& Dickens, 2000; Saxsena, 1999; Manos, 2002; Mollah, 2002; Amidu \& Abor, 2006; Al-Kuwari, 2009; Al-Shubiri, 2011). The researchers argue that high-risk firms will experience fluctuations in their cash flows more than low-risk firms. This might force them to look for external financing. They attempt to avoid costly and risky external financing by reducing dividend payout. A firm experiencing high systematic risk (uncertainty) will find it difficult to establish a relationship between current and future earnings. To cope with such uncertainty, the firm may reduce dividend payout. The firm will pay low dividend in order to maintain stable dividend payout in the future and avoid using costly external financing. On the other hand, a firm experiencing stable earnings is very likely to predict future earning at a relatively high degree of accuracy. It is then expected to have high dividend payout. It is, therefore, hypothesized that:

Hypothesis 7: Dividend payout is associated with business risk.

\subsection{Industry}

Industry type affects the capital structure of the firm and this impacts dividend payout. Hence, industry type in which a firm operates is expected to have a significant effect on corporate dividend policy. The nature of different industries affects dividend policy. For example, companies operating in the manufacturing industry will have machineries and equipment, while these type of assets are not important to the services industry. Manufacturing industry is capital intensive, while the services industry is labor intensive. More funding is required to finance capital investment than paying for employees. Hence, services companies are expected to have higher dividend payout than manufacturing companies.

The relationship between industry type and dividend policy has been empirically investigated in several studies (see for example: Bowen et al., 1982; Bradley et al., 1984; Kester, 1986; Baker, 1988; Harris \& Raviv, 1991; Dempsey et al., 1993; Richardson et al., 2002; Gill et al., 2010; Al Shabibi \& Ramesh, 2011, Subramaniam et al., 2011; Sarwar \& Naseem, 2014). Empirical evidence of the direction of the relationship between industry type and dividend policy is inconsistent. It is, therefore, hypothesized that:

Hypothesis 8: Dividend payout is associated with corporate industry type.

\section{Data Collection and Study Methodology}

\subsection{Data Collection}

As mentioned earlier, panel data were collected from the annual reports of all non-financial companies listed on ADX for the period between 2010-2012. In addition to the published annual reports, companies' profiles and details of majority shareholders were collected from ADX website.

At the end of 2012, the website of ADX indicated that 70 companies were listed on the Exchange. The companies are divided into 39 financial and 31 non-financial. While the financial companies include banks, insurance and investment companies, the non-financial companies comprise services, industrial, consumer staples, property and real estate, energy and telecommunications. The annual reports of one non-financial company were not published for any of the years covered in the current study. In addition, two non-Emirati companies appeared on the website: Ooredoo Telecom and Sudan Telecommunication Co. Ltd. These two companies are operating in two different Arab countries but they are listed on ADX as part of the cross- listing agreements between number of Arab exchanges. The non-financial companies are communications (1), Property and Real Estate (1), Energy (2), Food Staples (4), Services (6) and Manufacturing (14).

To identify the relationship between dividend payout and corporate attributes Ordinary Least Square (OLS) regression will be undertaken to estimate the following model.

$$
\operatorname{Div}_{(\text {payout })}=\beta_{0}+\beta_{1} S I Z+\beta P_{2} P R O F+\beta_{3} G R W+\beta_{4} O W N+\beta_{5} L E V+\beta_{6} F C F+\beta_{7} R I S K+\beta_{8} I N D S+\varepsilon
$$

Where,

Div $_{(\text {payout })}=$ Dividend Payout measured by annual cash dividends;

$\boldsymbol{\beta}_{\boldsymbol{0}}=$ Intercept; 
$\boldsymbol{\beta}_{0}-\boldsymbol{\beta}_{9}=$ Parameters of the model;

$\boldsymbol{S I Z}=$ Size measured by total Assets;

$\boldsymbol{P R O F}=$ Profitability measured by Return on Assets;

$\boldsymbol{G} \boldsymbol{R} \boldsymbol{W}=$ Growth measured by changes in fixed assets;

$\boldsymbol{O} \boldsymbol{W N}=$ Ownership measured by percentage of shares owned by majority shareholders;

$\boldsymbol{L E} \boldsymbol{V}=$ Leverage measured by Total Liabilities/ Total Assets;

$\boldsymbol{F C F}=$ Free Cash Flows measured by annual net income minus changes in current assets and changes in fixed assets;

$\boldsymbol{R I S K}=$ Risk is measured by the standard deviation of the company's return to the market return;

IDS $=$ Industry: 1 Services, 2 Manufacturing, 3 Food Staples, 4 Property and Real Estate, 5 Energy, 6 Communications;

$\boldsymbol{E}=$ Standard Error.

\section{Findings}

\subsection{Descriptive Statistics}

21 of the surveyed non-financial companies listed on ADX paid dividends in each of the three years covered in the study, 2 paid dividends in only two years, 2 paid dividends in only one year and 3 companies did not pay dividends in any of the three years. The mean of dividends paid by all surveyed companies during 3 years covered in the study was AED 222 million as summarized in Table 1. Dividend paid during the period of study ranges between zero and up to AED 4,744 million. Descriptive statistics summarized in Table 1 also pointed to significant variation in the characteristics of the non-financial companies listed on ADX. They vary in their size, profitability, ownership structure, growth in their fixed assets, level of leverage, level of risk and the amount of free cash flows. Significant variations among surveyed companies form good basis for analysis and give credibility to the outcome.

Table 1. Descriptive statistics of variables used in the study

\begin{tabular}{lccccc}
\hline & Mean & Median & Standard Deviation & Minimum & Maximum \\
\hline Cash Dividends (AED Million) & 222 & 21 & 867 & 0.00 & 4,744 \\
SIZ (AED Million) & 10,139 & 1,610 & 25,705 & 189 & 124,683 \\
PROF (ROA) & 0.03 & 0.03 & 0.06 & -0.27 & 0.18 \\
GRW (AED Million) & 167 & 34 & 2,714 & $-11,195$ & 19,012 \\
OWN & 0.57 & 0.61 & 0.24 & 0.00 & 0.98 \\
LEV & 0.15 & 0.08 & 0.18 & 0.00 & 0.79 \\
FCF (AED Million) & 316 & 36 & 3,291 & $-12,658$ & 20,638 \\
RISK (Million) & $3,468,921$ & 45,709 & $19,560,308$ & 235 & 166,508 \\
\hline
\end{tabular}

\subsection{Correlation among the Independent Variables}

Before undertaking the multiple regression, it was important to identify possible collinearity among the independent variables. Hence, two-tail Pearson correlation was undertaken and the result of the correlation is summarized in Table 2.

Table 2. Correlations between independent variables used in the regression model

\begin{tabular}{|c|c|c|c|c|c|c|c|c|}
\hline & $S I Z$ & PROF & GRW & $O W N$ & $L E V$ & $F C F$ & RISK & IDS \\
\hline \multirow[t]{2}{*}{$S I Z$} & 1.000 & & & & & & & \\
\hline & 0.000 & & & & & & & \\
\hline \multirow[t]{2}{*}{ PROF } & $-.068-$ & 1.000 & & & & & & \\
\hline & .541 & 0.000 & & & & & & \\
\hline \multirow[t]{2}{*}{$G R W$} & $.411 * *$ & $.256^{*}$ & 1.000 & & & & & \\
\hline & .000 & .019 & 0.000 & & & & & \\
\hline$O W N$ & $-.013-$ & $-.056-$ & $.216^{*}$ & 1.000 & & & & \\
\hline
\end{tabular}




\begin{tabular}{|c|c|c|c|c|c|c|c|c|}
\hline & .910 & .616 & .049 & 0.000 & & & & \\
\hline \multirow[t]{2}{*}{$L E V$} & $.581 * *$ & $-.112-$ & $.335 * *$ & .002 & 1.000 & & & \\
\hline & .000 & .311 & .002 & .986 & 0.000 & & & \\
\hline \multirow[t]{2}{*}{$F C F$} & .018 & $.352 * *$ & .054 & $-.111-$ & -.224 -* $^{*}$ & 1.000 & & \\
\hline & .869 & .001 & .625 & .316 & .041 & 0.000 & & \\
\hline \multirow[t]{2}{*}{ RISK } & $.336 * *$ & $-.491-* *$ & $-.376-* *$ & $-.170-$ & .147 & $-.264-*$ & 1.000 & \\
\hline & .002 & .000 & .000 & .121 & .184 & .015 & 0.000 & \\
\hline \multirow[t]{2}{*}{$I D S$} & $.721 * *$ & $-.200-$ & .161 & -.038 & .189 & .196 & $.344 * *$ & 1.000 \\
\hline & .000 & .068 & .143 & .733 & .085 & .073 & .001 & 0.000 \\
\hline
\end{tabular}

Note. $* *$. Correlation is significant at the 0.01 level (2-tailed).

*. Correlation is significant at the 0.05 level (2-tailed).

Table 2 pointed to few significant correlations among the independent variables. Positive and significant association was reported between corporate size and each of growth, leverage, risk and industry type. Positive and significant correlations also spotted between profitability and growth, profitability and free cash flows and industry and risk. On the other hand, negative and significant correlations appeared between profitability and risk, growth and risk and leverage and free cash flows. Although the Pearson correlation pointed to a number of correlations among the independent variables, this does not mean that collinearity is not a problem. Since the sample in the current study is relatively small, Pearson correlation can be misleading. For example, moderate correlation in a sample with few observations might not in reality reach a high degree of significance. In all cases, other measures were taken to insure that collinearity among the independent variables is not a serious problem in the current study. This includes VIF test and backward regression.

\subsection{Regression Results}

Backward regression was performed and the result of the regression is reported in Table 3. It is obvious from the two models resulted from the backward regression that all explanatory variables estimated in the regression model are significantly related to cash dividend except the growth variable. Although growth in fixed assets is negatively related to cash dividend, the relationship between the two variables is statistically insignificant. On the other hand, all other explanatory variables used to estimate the regression model and showed significant association with cash dividend were positive except for the level of leverage.

Table 3. Regression analysis

\begin{tabular}{llllll}
\hline Model 1 & $\mathrm{R}^{2}=0.669$ & Adjusted $\mathrm{R}^{2}=0.634$ & $\mathrm{~F}=18.96$ & \multicolumn{2}{l}{ Sig. $\mathrm{F}=0.00$} \\
& Variables & Beta & $\mathrm{t}$ & Sig. & VIF \\
& Constant & & $-2.503-$ & .015 & \\
& SIZ & .410 & 3.256 & .002 & 3.587 \\
& PROF & .369 & 4.455 & .000 & 1.551 \\
& GRW & $-.073-$ & $-.770-$ & .444 & 2.031 \\
& OWN & .175 & 2.488 & .015 & 1.122 \\
& LEV & $-.172-$ & $-2.239-$ & .028 & 1.341 \\
& FCF & .271 & 3.392 & .001 & 1.444 \\
& RISK & .434 & 4.330 & .000 & 2.273 \\
& IDS & .218 & 2.058 & .043 & 2.545 \\
\hline Model 2 & R $=0.666$ & Adjusted $\mathrm{R}^{2}=0.636$ & $\mathrm{~F}=21.69$ & Sig. F $=0.00$ & \\
\hline & Variables & Beta & $\mathrm{t}$ & Sig. & \\
& Constant & & $-2.460-$ & .016 & \\
& SIZ & .359 & 3.356 & .001 & 2.606 \\
& PROF & .363 & 4.419 & .000 & 1.541 \\
& OWN & .165 & 2.396 & .019 & 1.087 \\
& LEV & $-.170-$ & $-2.218-$ & .030 & 1.339 \\
FCF & .279 & 3.545 & .001 & 1.415 \\
RISK & .473 & 5.522 & .000 & 1.673 \\
IDS & .226 & 2.144 & .035 & 2.524 \\
\hline
\end{tabular}




\section{Conclusion}

The main purpose of this study was to establish the relationship between dividend policy of and number of corporate attributes of companies listed on ADX. Panel data were collected from the annual reports of the listed companies for the years 2010-2012 and regressed against 8 explanatory variables. 7 out of the 7 variables appeared to significantly associated with dividend policy. 6 out of these 7 variables showed significant and positive association with dividend policy: size, profitability, ownership, free cash flows, risk and industry. One variables (leverage) showed significant, but negative association with dividend policy. This implies that large sized, profitable, highly concentrated ownership, availability of free cash flows and high levels of risk will force non-financial companies listed on ADX management to pay high levels of dividends. Companies with high levels of leverage, however, are expected to pay less dividends. It is, therefore, fair to say that the result is not in line with agency theory.

\section{Acknowledgements}

Views and opinions expressed in this article are those of the authors and do not relflect views ansd opinions of their employers.

\section{References}

Abdelsalam, O., El-Masry, A., \& Elsegini, S. (2008). Board Composition, Ownership Structure and Dividend Policies in an Emerging Market Further Evidence from CASE 50. Managerial Finance, 12, 953-964.

Adaoglu, C. (2000). Instability in the Dividend Policy of the Istanbul Stock Exchange (ISE) Corporations: Evidence from an Emerging Market. Emerging Markets Review, 252-270. http://dx.doi.org/10.1016/S1566-0141(00)00011-X

Agrawal, A., \& Jayaraman, N. (1994). The Dividend Policies of all Equity Firms: A Direct test of Free Cash Flow Theory. Managerial Decision Economics, 15, 139-148. http://dx.doi.org/10.1002/mde.4090150206

Al-Kuwari, D. (2009). Determinants of the Dividend Policy in Emerging Stock Exchanges: The Case of GCC Countries. Global Economy \& Finance Journal, 2(2), 38-63.

Alli, K., Khan, A., \& Ramirez, G. (1993). Determinants of Dividend Policy: A Factorial Anlysis. The Financial Review, 28(4), 523-547. http://dx.doi.org/10.1111/j.1540-6288.1993.tb01361.x

Al-Shubiri, F. N. (2011). Determinants of Changes Dividend Behavior Policy: Evidence from the Amman Stock Exchange. Far East Journal of Psychology and Business, 4(1), 1-15.

Amidu, M., \& Abor, J. (2006). Determinants of dividend payout ratios in Ghana. The Journal of Risk Finance, 7 , 136-145. http://dx.doi.org/10.1108/15265940610648580

Asif, A., Rasool, L. W., \& Kama, Y. (2011). Impact of financial leverage on dividend policy: Empirical evidence from Karachi Stock Exchange-listed. African Journal of Business Management, 5(4), 1312-1324.

Baah, B. K., Tawiah, R., \& Opoku, F. E. (2014). Industry Sector Determinants of Dividend Policy and its Effect On Share Prices in Ghana. International Journal of Economics, Business and Finance, 2(5), 1-19.

Baker, H. K. (1988). Relationship between Industry Classification and Dividend Policy. Southern Business Review, 14(1), 1-8.

Barclay, M., \& Holderness, C. (1992). The law and large-block trades. Journal of Law and Economics, 35(2), 265-294. http://dx.doi.org/10.1086/467254

Bebchuk, L. A. (1999). A Rent-Protection Theory of Corporate Ownership and Control. Working Paper, No. 7203, National Bureau of Economic Research, (Cambridge, MA). http://dx.doi.org/10.2139/ssrn.168990

Bowen, R. M., Daley, L. A., \& Huber, Jr. C. C. (1982). Evidence on the Existence and Determinants of Inter-Industry Leverage Differences. Financial Management, 11, 10-20. http://dx.doi.org/10.2307/3665227

Bradley, M., Jarrell, G., \& Kim, E. H. (1984). On the Existence of an Optimal Capital Structure: Theory and Evidence. Journal of Finance, 39, 857-878. http://dx.doi.org/10.1111/j.1540-6261.1984.tb03680.x

Bradley, M., Capozza, D. R., \& Seguin, P. J. (1998). Dividend Policy and Cash-flow Uncertainty. Real Estate Economics, 26(4), 555-580. http://dx.doi.org/10.1111/1540-6229.00757

Chen, C. R., \& Steiner, T. L. (2005). Managerial Ownership and Agency Conflicts: A Nonlinear Simultaneous Equation Analysis of Managerial Ownership, Risk Taking, Debt Policy, and Dividend Policy. The Financial Review, 34(1), 19-136. 
Cheng, Z., Cullinan, C. P., \& Zhang, J. (2014). Free Cash Flow, Growth Opportunities, and Dividends: Does Cross-Listing of Shares Matter? The Journal of Applied Business Research, 30(2), 587-598.

Casey, K. M., \& Dickens, R. N. (2000). Effects of Tax and Regulatory Changes on Commercial Bank Dividend Policy. The Quarterly Review of Economic and Finance, 40(2), 9-33. http://dx.doi.org/10.1016/S1062-9769(99)00051-4

Crutchley, C., \& Hansen, R. (1987). A Test of the Agency Theory of Managerial Ownership, Corporate Leverage and Corporate Dividends. Financial Management, 18, 36-46. http://dx.doi.org/10.2307/3665795

Dempsey, S. J., Laber, G., \& Rozeff, M. S. (1993). Dividend Policies in Practice: Is There an Industry Effect? Journal of Business and Economics, 32(4), 3-13.

Denis, D., Denis, D., \& Sarin, A. (1994). The Information Content of Dividend Changes: Cash Flow Signaling, Overinvestment, and Dividend Clienteles. Journal of Financial and Quantitative Analysis, 29, 567-587. http://dx.doi.org/10.2307/2331110

D’Souza, J., \& Saxena, A. K. (1999). Agency Cost, Market Risk, Investment Opportunities and Dividend PolicyAn International Perspective. Managerial Finance, 25(6), 35-43. http://dx.doi.org/10.1108/03074359910765993

Eddy, A., \& Seifert, B. (1988). Firm Size and Dividend Announcements. Journal of Financial Research, 11, 295-302. http://dx.doi.org/10.1111/j.1475-6803.1988.tb00090.x

Eriotis, N., \& Vasiliou, D. (2006). The Link between Dividend Policy and Corporate Leverage: An Empirical Analysis of the Greek Market. Spoudai, 56(1), 64-75.

Fairchild, R. (2010). Dividend policy, Signaling and Free Cash Flow: An Integrated Approach. Managerial Finance, 36(5), 394-413. http://dx.doi.org/10.1108/03074351011039427

Fama, E. F., \& French, K. R. (2000). Testing Tradeoff and Pecking Order Predictions about Dividends and Debt. The Center for research in Security Prices Working Paper 506.

Fama, E. F., \& French, K. R. (2001). Disappearing Dividends: Changing Firm Characteristics or Lower Propensity to Pay? Journal of Financial Economic, 60, 3-43. http://dx.doi.org/10.1016/S0304-405X(01)00038-1

Fan, H., \& Sundaresan, S. M. (2000). Debt Valuation, Renegotiation, and Optimal Dividend Policy. The Review of Financial Studies, 13(4), 1507-1099. http://dx.doi.org/10.1093/rfs/13.4.1057

Frankfurter, G. M. (1999). What is the Puzzle in "The Dividend Puzzle"? The Journal of Investing, 8(2), 76-85. http://dx.doi.org/10.3905/joi.1999.319407

Franklin, J., \& Muthusamy, K. (2010). Leverage, Growth and Profitability as Determinants of Dividend Payout Ratio-Evidence from Indian Paper Industry. Asian Journal of Business Management Studies, 1(1), 26-30.

Fudenberg, D., \& Tirole, J. (1995). A Theory of Income and Dividends Smoothing Based on Incumbency Rents. Journal of Political Economy, 103(1), 75-93. http://dx.doi.org/10.1086/261976

Gadhoum, Y. (2000). Family Control and Grouping: Possible Expropriation Via Dividends. Working Paper, CENTOR.

Gill, A., Nahum, B., \& Tibrewala, R. (2010). Determinants of Dividend Payout Ratios: Evidence from United States. The Open Business Journal, 3, 8-14. http://dx.doi.org/10.2174/1874915101003010008

Gugler, K., \& Burcin, Y. (2003). Corporate Governance and Dividend Pay-Out Policy in Germany. European Economic Review, 47, 731-758. http://dx.doi.org/10.1016/S0014-2921(02)00291-X

Han, K. C., Lee, S. H., \& Suk, D. Y. (1999). Institutional Shareholders and Dividends. Journal of Financial and Strategic Decisions, 12(1), 53-62.

Harris, M., \& Raviv, A. (1991). The Theory of Capital Structure. Journal of Financial Economics, 41, $297-355$. http://dx.doi.org/10.1111/j.1540-6261.1991.tb03753.x

Holder, M., Langrehr, F., \& Hexter, J. (1998). Dividend Policy Determinants: An Investigation of the Influences of Stakeholder Theory. Financial Management, 27, 73-82. http://dx.doi.org/10.2307/3666276

Jain, R. (2007). Institutional and Individual Investor Preferences for Dividends and Share Repurchases. Journal of Economics and Business, 59, 406-429. http://dx.doi.org/10.1016/j.jeconbus.2007.04.004

Jensen, M., \& Meckling, W. (1976). Theory of the Firm: Managerial Behavior, Agency Costs, and Ownership Structure. Journal of Financial Economics, 4, 305-360. http://dx.doi.org/10.1016/0304-405X(76)90026-X 
Jensen, M., Solberg, D., \& Zone, T. (1992). Simultaneous Determination of Insider Ownership, Debt, and Dividend Policies. Journal of Financial and Quantitative Analysis, 27(2), 247-263. http://dx.doi.org/10.2307/2331370

Kester, W. (1986). Capital and Ownership Structure: A Comparison of United States and Japanese Manufacturing Corporations. Financial Management, 15, 5-6. http://dx.doi.org/10.2307/3665273

Kim, S., Sul, W., \& Kang, S. A. (2010). Impact of Foreign Institutional Investors on Dividend Policy in Korea: A Stock Market Perspective. Journal of Financial Management and Analysis, 23(1), 10-26.

Kim Thu, N., Triên, L. V., Thúy, D. T. A., \& Nhon, H. (2013). Determinants of Dividend Payments of Non-financial Listed Companies in Ho Chí Minh Stock Exchange. VNU Journal of Economics and Business, 29(5), 16-33.

Kouki, M., \& Guizani, M. (2009). Ownership Structure and Dividend Policy Evidence from the Tunisian Stock Market. European Journal of Scientific Research, 25(1), 42-53.

Kumar, B. R., \& Abdul Waheed, K. (2015). Determinants of Dividend Policy: Evidence from GCC Market. Accounting and Finance Research, 4(1), 17-29.

Lang, L. H. P., \& Litzenberger, R. H. (1989). Dividend Announcements: Cash Flow Signaling versus Free Cash Flow Hypothesis? Journal of Financial Economics, 24, 181-192. http://dx.doi.org/10.1016/0304-405X(89)90077-9

La Porta, R., Florencio, L., \& Andrei, S. (1999). Corporate Ownership around the World. Journal of Finance, 54, 471-517. http://dx.doi.org/10.1111/0022-1082.00115

La Porta, R., Lopez-De Salinas, F., Shleifer, A., \& Vishny, R. (2000). Agency Problems and Dividend Policy around the World. Journal of Finance, 55(1), 1-33. http://dx.doi.org/10.1111/0022-1082.00199

Lloyd, W., Jahera, J., \& Page, D. (1985). Agency Costs and Dividend Payout Ratios. Quarterly Journal of Business and Economics, 24, 19-29.

Manos, R. (2002). Dividend Policy and Agency Theory: Evidence on Indian Firms. Working Paper, Institute for Development Policy and Management, University of Manchester.

McKnight, P., \& Weir, C. (2009). Agency Costs, Corporate Governance Mechanisms and Ownership Structure in Large UK Publicly Quoted Companies: A panel data analysis. The Quarterly Review of Economics and Finance, 49(2), 139-158. http://dx.doi.org/10.1016/j.qref.2007.09.008

Mehrani, S., Moradi, M., \& Eskandar, H. (2011). Ownership structure and dividend policy: Evidence from Iran. African Journal of Business Management, 5(17), 7516-7525.

Meyers, S. C., \& Majluf, N. S. (1984). Corporate Financing and Investment Decisions When Firms Have Information that Investors Do Not Have. Journal of Financial Economics, 13, 187-221. http://dx.doi.org/10.1016/0304-405X(84)90023-0

Mohd, M., Perry, L., \& Rimbey, J. (1995). An Investigation of Dynamic Relationship between Agency Theory and Dividend Policy. The Financial Review, 30, 367-385. http://dx.doi.org/10.1111/j.1540-6288.1995.tb00837.x

Mollah, S., Keasey, K., \& Short, H. (2002). The Influence of Agency Costs on Dividend Policy in an Emerging Market: Evidence from the Dhaka Stock Exchange. Working Paper. Retrieved from http://www.bath.ac.uk

Morck, R., Andrei, S., \& Robert, W. V. (1988). Management Ownership and Market Valuation: An Empirical Analysis. Journal of Financial Economics, 20, 293-315. http://dx.doi.org/10.1016/0304-405X(88)90048-7

Movalia, N., \& Vekariya, P. (2014). A Study on Determinants of Dividend Policy and Its impact on Dividend of Listed Company Under S \& P BSE SENEX. Journal of Business Management and Social Science, 3(12), 70-72.

Murali, R., \& Welch, J. (1989). Agents, Owners, Control and Performance. Journal of Business Finance \& Accounting, Summer, 385-298. http://dx.doi.org/10.1111/j.1468-5957.1989.tb00025.x

Naser, K., Nuseibeh, R., \& Rashed, W. (2013). Managers' Perception of Dividend Policy: Evidence from Companies Listed on Abu Dhabi Securities Exchange. Issues in Business Management and Economics, 1(1), $1-12$.

Nnadi, M. A., \& Akpomi, M. (2008). The Effect of Taxes on Dividend Policy of Banks in Nigeria. International Research Journal of Finance and Economics, 19, 48-55. 
Redding, L. (1997). Firm Size and Dividend Payouts. Journal of Financial Intermediation, 6, $224-248$. http://dx.doi.org/10.1006/jfin.1997.0221

Renneboog, L., \& Peter, S. (2007). How Relevant is Dividend Policy under Low Shareholder protection? ECGI, Finance Working Paper, No 128.

Richardson, S., Tuna, I., \& Wu, M. (2002). Predicting earnings management: The case of earnings restatements. Unpublished working paper, October version.

Rozeff, M. S. (1982). Growth, Beta and Agency Costs as Determinants of Dividend Payout Ratios. The Journal of Financial Research, 249-259. http://dx.doi.org/10.1111/j.1475-6803.1982.tb00299.x

Saeed, R., Riaz, A., Lodhi, R. N., \& Munir, H. M. (2014). Determinants of Dividend Payouts in Financial Sector of Pakistan. Journal of Basic and Applied Scientific Research, 33-42.

Sáez, M., \& Gutiérrez, M. (2014). Dividend Policy with Controlling Shareholders. Theoretical Inquiries in Law, 16(1), 107-130.

Salehnezhad, S. H. (2013). A Study Relationship between Firm Performance and Dividend Policy by Fuzzy Regression: Iranian Scenario. International Journal of Accounting and Financial Reporting, 3(2), 70-75. http://dx.doi.org/10.5296/ijafr.v3i2.4072

Sarwar, R., \& Naseem, N. (2014). Review of Dividend Policy and its Impact on Shareholders Wealth. International Journal of Management \& Organizational Studies, 3(4), 24-28.

Sawicki, J. (2005). An Investigation into the Dividend of Firms in East Asia. Working Paper, Nanyang Technological University, Singapore.

Saxena, A. (1999). Determinants of Dividend Policy: Regulated Versus Unregulated Firms. Financial Management Association Conference.

Schooley, D., \& Barney, D. (1994). Using Dividend Policy and Managerial Ownership to Reduce Agency Costs. Journal of Financial Research, 17, 363-373. http://dx.doi.org/10.1111/j.1475-6803.1994.tb00198.x

Shleifer, A., \& Robert, V. (1986). Large shareholders and corporate control. Journal of Political Economy, 94, 461-488. http://dx.doi.org/10.1086/261385

Short, H., Zhang, H., \& Keasey, K. (2002). The Link between Dividend Policy and Institutional Ownership. Journal of Corporate Finance, 8, 105-122. http://dx.doi.org/10.1016/S0929-1199(01)00030-X

Subramaniam, R., Devi, S. S., \& Marimuthu, M. (2011). Investment Opportunity Set and Dividend Policy. Malaysia African Journal of Business Management, 5(24), 10128-10143.

Thanatawee, Y. (2011). Life-Cycle Theory and Free Cash Flow Hypothesis: Evidence from Dividend Policy in Thailand. International Journal of Financial Research, 2, 52-60. http://dx.doi.org/10.5430/ijfr.v2n2p52

Thanatawee, Y. (2013). Ownership Structure and Dividend Policy: Evidence from Thailand. International Journal of Economics and Finance, 5(1), 121-132.

Titman, S., \& Wessels, R. (1988). The Determinants of Capital Structure Choice. The Journal of Finance, 43(1), 1-19. http://dx.doi.org/10.1111/j.1540-6261.1988.tb02585.x

Truong, T. H., \& Heaney, R. (2007). Largest Shareholder and Dividend Policy Around the World. The Quarterly Review of Economics and Finance, 47, 667-687. http://dx.doi.org/10.1016/j.qref.2007.09.002

Utami, S. R., \& Inanga, E. L. (2011). Agency Cost of Free Cash Flow, Dividend Policy, and Leverage of Firms in Indonesia. European Journal of Economics, Finance and Administrative Science, 33, 7-24

Wang, M., Gao, S., \& Guo, G. (2002). Dividend Policy of China Listed Companies. Working Paper.

\section{Notes}

Note 1. Any views expressed in this paper are those of the authors only and not those of their employers.

Note 2. Some managers tend to increase the dividend payout and force themselves to borrow. This move subjects management to the scrutiny of a third party (lender) to assure shareholders and minimize agency costs. 


\section{Copyrights}

Copyright for this article is retained by the author(s), with first publication rights granted to the journal.

This is an open-access article distributed under the terms and conditions of the Creative Commons Attribution license (http://creativecommons.org/licenses/by/3.0/). 